\title{
Development of the smoky brown cockroach, Periplaneta fuliginosa, in relation to resistance to cold
}

\author{
Hideakira TSUJI* \\ Agricultural Chemicals Research Laboratories, Sankyo Co., Ltd., \\ Yasu, Yasu-cho, Shiga-ken 520-23, Japan \\ (Received: October 20, 1974)
}

\begin{abstract}
A preliminary exposure of more than 28 days to $15^{\circ} \pm 1^{\circ} \mathrm{C}$ and short day length could induce final instar nymyhs of $P$. fuliginosa to tolerate a chilling temperature of $5.5^{\circ} \pm 0.5^{\circ} \mathrm{C}$ for 90 days. The nymphs seem to enhance their resistance to cold without entering "true diapause". Second instar nymphs reared at $15^{\circ} \pm 1^{\circ} \mathrm{C}$ seem to be more resistant to cold than those reared at $20^{\circ} \pm 1^{\circ} \mathrm{C}$.
\end{abstract}

\section{INTRODUCTION}

It has been reported that older nymphs of the smoky brown cockroach, Periplaneta fuliginosa, survived for 90 days at $5.5^{\circ} \pm$ $0.5^{\circ} \mathrm{C}$ that followed an exposure to $15^{\circ} \pm 1^{\circ} \mathrm{C}$ for 28 days, suggesting that the nymphs can overwinter outdoors in Central Japan (Tsuji and Mizuno, 1973).

Many insect species in the temperate zone overwinter in a state of arrested development called "diapause", and the state of diapause is often characterized by enhanced resistance to unfavourable climatic conditions (Bonnemaison, 1945 ; Bodenheimer, 1952 ; Andrewartha, 1952 ; Lees, 1955). The enhanced resistance seems to be a secondary adaptation which permits the diapause individuals to survive in an adverse environment (Lees, 1955 ; Tsuji, 1963).

Tsuji and Mizuno $(1972,1973)$ have already shown that $P$. japonica enters diapause at the second and final nymphal instar stages. However, we have not as yet sufficient data on $P$. fuliginosa. In the present study, experiments were carried out to investigate the nature of the enhancement of resistance to cold in nymphs of $P$. fuliginosa especially

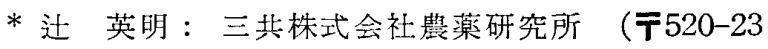
滋賀県野州郡野州町) in relation to diapause phenomena.

\section{Materials AND METHOD}

The stock colony of $P$. fuliginosa was started from individuals captured in Tokyo, and has been maintained in the laboratory for more than 10 years at $27^{\circ} \pm 1^{\circ} \mathrm{C}$. The food (Animal pellets "Oriental Rat Food MF and NMF"') and containers used for the experiments were essentially the same as described in previous papers (Tsuji, 1965; Tsuji and Mizuno, 1972, 1973). Rearing and chilling conditions were also the same that used before (Tsuji and Mizuno, 1972, 1973) as follows.

$27^{\circ} \mathrm{C}$-L : $27^{\circ} \pm 1^{\circ} \mathrm{C}, 60 \%$ to $80 \%$ R.H., 16 $\mathrm{hr}$ illumination per day.

$20^{\circ} \mathrm{C}-\mathrm{S}$ : $20^{\circ} \pm 1^{\circ} \mathrm{C}, 50 \%$ to $70 \%$ R.H., 8 hr illumination per day.

$15^{\circ} \mathrm{C}-\mathrm{S}$ : $\quad 15 \pm 1^{\circ} \mathrm{C}$, uncontrolled R.H., $8 \mathrm{hr}$ illumination per day.

Chilling : $5.5 \pm 0.5^{\circ} \mathrm{C}$, almost saturated R. $H$. if not specially described, usually in darkness.

Other details will be described for each experiment.

\section{REsults AND DisCUSSION}

I. Effect of an exposure of final instar nymphs to $15^{\circ} \mathrm{C}-\mathrm{S}$ on the enhancement of their 


\section{resistance to cold}

Final instar nymphs soon after moulting were taken from a stock colony in which nymphs had been reared at $27^{\circ} \mathrm{C}-\mathrm{L}$ for 90 days from their hatching. The nymphs were then reared at $15^{\circ} \mathrm{C}-\mathrm{S}$ for different periods of time. After that, they were chilled at $5.5^{\circ} \pm 0.5^{\circ} \mathrm{C}$ also for different days. Survival of the nymphs was determined on the 7 th day after returning them to $27^{\circ} \mathrm{C}-\mathrm{L}$.

The results are shown in Table 1 . The preliminary exposure to $15^{\circ} \mathrm{C}-\mathrm{S}$ for less than 18 days was not sufficient to induce the nymphs to tolerate the chilling treatment of
90 days, but the preliminary exposure for more than 28 days was clearly effective.

II. Effect of an intervening exposure to $15^{\circ} \mathrm{C}-\mathrm{S}$ on further development of final instar nymphs at $27^{\circ} \mathrm{C}-L$

In view of the fact that older nymphs of $P$. fuliginosa can enhance their resistance to cold when reared at $15^{\circ} \mathrm{C}-\mathrm{S}$ (Table 1 ), one can venture a hypothesis that the nymphs enter diapause at this temperature. While, as described by Lees (1955), " many insects in a state of diapause die without developing or grow in a protracted and irregular manner

Table 1 Preliminary exposure of final instar nymphs to $15^{\circ} \mathrm{C}-\mathrm{S}$ and enhancement of theis resistance to cold $\left(5.5^{\circ} \mathrm{C} \pm 0.5^{\circ} \mathrm{C}\right)$

\begin{tabular}{|c|c|c|c|c|c|c|c|}
\hline \multirow{3}{*}{\multicolumn{2}{|c|}{$\begin{array}{l}\text { Temperature } \\
\text { and days of } \\
\text { preliminary } \\
\text { exposure }\end{array}$}} & \multicolumn{6}{|c|}{$\begin{array}{l}\text { Days of exposure to cold and } \\
\% \text { survival of nymphs }\end{array}$} \\
\hline & & \multicolumn{3}{|c|}{ Males } & \multicolumn{3}{|c|}{ Females } \\
\hline & & 30 & 60 & 90 & 30 & 60 & 90 \\
\hline \multirow[t]{7}{*}{$15^{\circ} \mathrm{C}-\mathrm{S}$} & 0 & 0 & & & 0 & & \\
\hline & 3 & 0 & & & 0 & & \\
\hline & 6 & 30 & 0 & & 80 & 0 & \\
\hline & 9 & 100 & 0 & 0 & 88 & 0 & 0 \\
\hline & 18 & 100 & 67 & 0 & 100 & 0 & 0 \\
\hline & 28 & 67 & 57 & 60 & 100 & 88 & 40 \\
\hline & 60 & 100 & 70 & 60 & 100 & 80 & 70 \\
\hline \multirow[t]{3}{*}{$27^{\circ} \mathrm{C}-\mathrm{L}$} & 1 & 0 & 0 & & 0 & 0 & \\
\hline & 3 & 10 & 0 & & 0 & 0 & \\
\hline & 9 & 10 & 0 & & 20 & 0 & \\
\hline
\end{tabular}

Six to seventeen nymphs were used in each treatment.

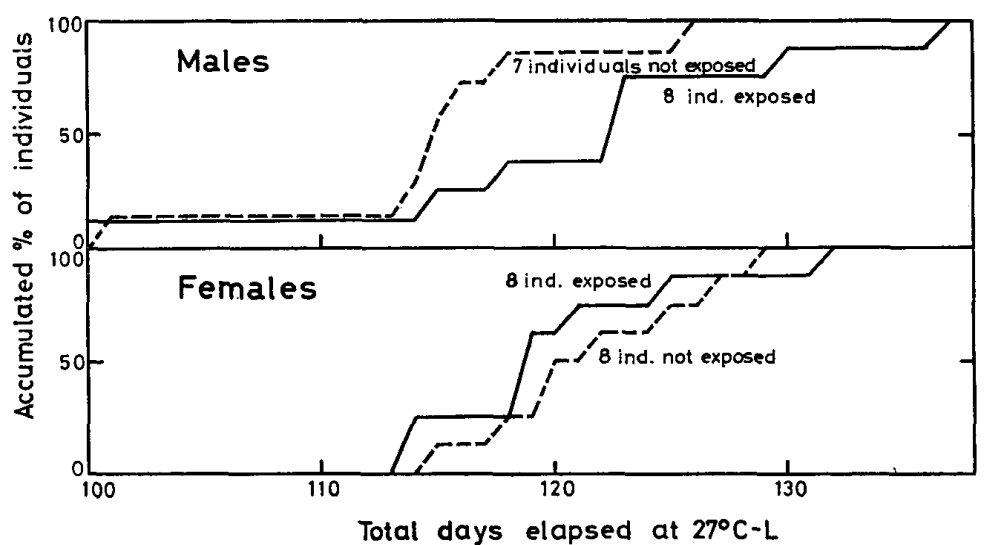

Fig. 1 Accumulated adult emergence curves for nymphs reared at $27^{\circ} \mathrm{C}-\mathrm{L}$ with or without an intervening exposure of 60 days to $15^{\circ} \mathrm{C}-\mathrm{S}$

-: Nymphs exposed on the 100th day.

- - : Nymphs not exposed. 
when exposed to temperatures that would be expected to favour morphogenesis ".

To investigate this possibility in $P$. fuliginosa, adult emergence from the nymphs which had been reared at $27^{\circ} \mathrm{C}$-L, with an intervening exposure to $15^{\circ} \mathrm{C}$-S for 60 days at the final instar stage, was examined. A slight but no extreme retardation of adult emergence was found in the results (Fig. 1).

III. Changes of dry matter and fat content of final instar nymphs at $15^{\circ} \mathrm{C}-\mathrm{S}$

The state of diapause is usually characterized by increased reserves or an excess of dry matter (Sacharov, 1930; Buxton, 1930; Mellanby, 1938; Squire, 1940; Levenbook, 1951 ; Fukaya, 1951 ; Koidsumi, 1951 ; Ushatinskaya, 1952 ; cited in Lees 1955 ; Ikemoto, 1958; Tsuji, 1963). So the changes of percentage dry matter and fat content of 8th (final) instar nymphs of $P$. fuliginosa at $15^{\circ} \mathrm{C}-\mathrm{S}$ were determined.

Final instar nymphs soon after moulting were obtained from a stock colony in which the nymphs had been reared at $27^{\circ} \mathrm{C}$-L for 88 days from their hatching. The nymphs were then transferred to and reared at $15^{\circ} \mathrm{C}$-S. Determinations of body weight, dry weight, and fat content of the nymphs were carried out after $0,60,90,120$, and 150 days rearing at $15^{\circ} \mathrm{C}$-S. On each determination, several individuals were taken and individually weighed before and after complete drying at $105^{\circ} \mathrm{C}$, as well as before and after fat extraction in a Soxhlet equipment with ether. The results in females are shown in Fig. 2.

The determinations were also made in fully grown 7th instar nymphs, 8th (final) instar nymphs of known age, and young adults which were reared at $27^{\circ} \mathrm{C}$-L. The results in females are shown in Fig. 3.

Figure 2 indicates that the dry matter and fat content of final instar nymphs increased with increased body weight at $15^{\circ} \mathrm{C}-\mathrm{S}$, though the nymphs grew very slowly at this temperature. However, this is not characteristic in the nymphs reared at $15^{\circ} \mathrm{C}-\mathrm{S}$, because the increased dry matter and fat content were also observed in the final instar nymphs reared at $27^{\circ} \mathrm{C}-\mathrm{L}$ (Fig. 3). Figure 3 also shows that the dry matter and

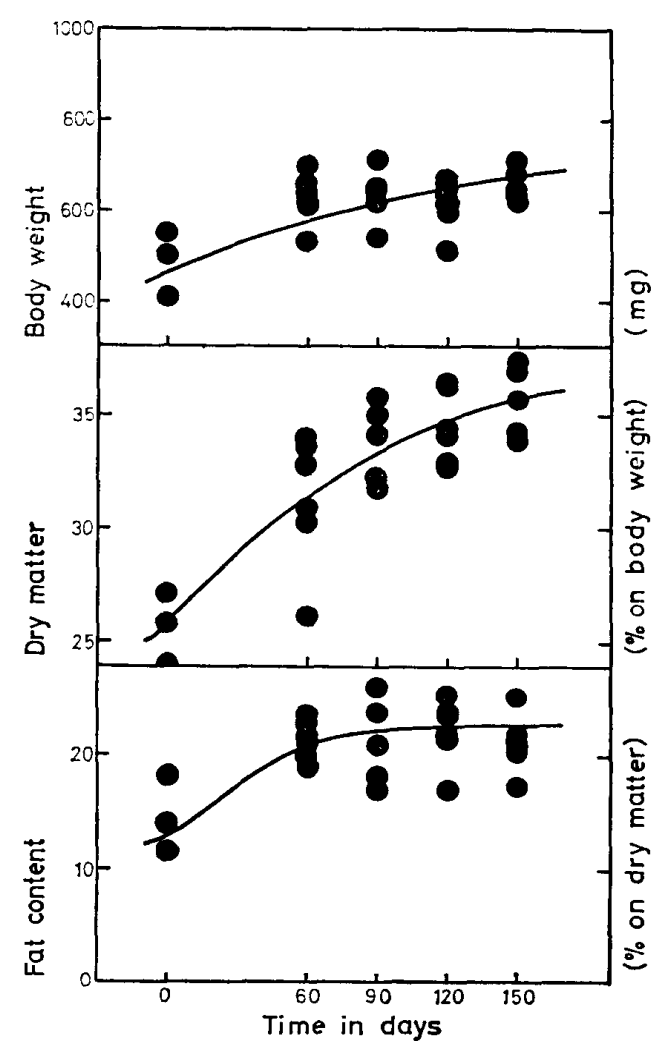

Fig. 2 Changes of body weight, dry matter, and fat content of final instar nymphs at $19^{\circ} \mathrm{C}-\mathrm{S}$ (Females)

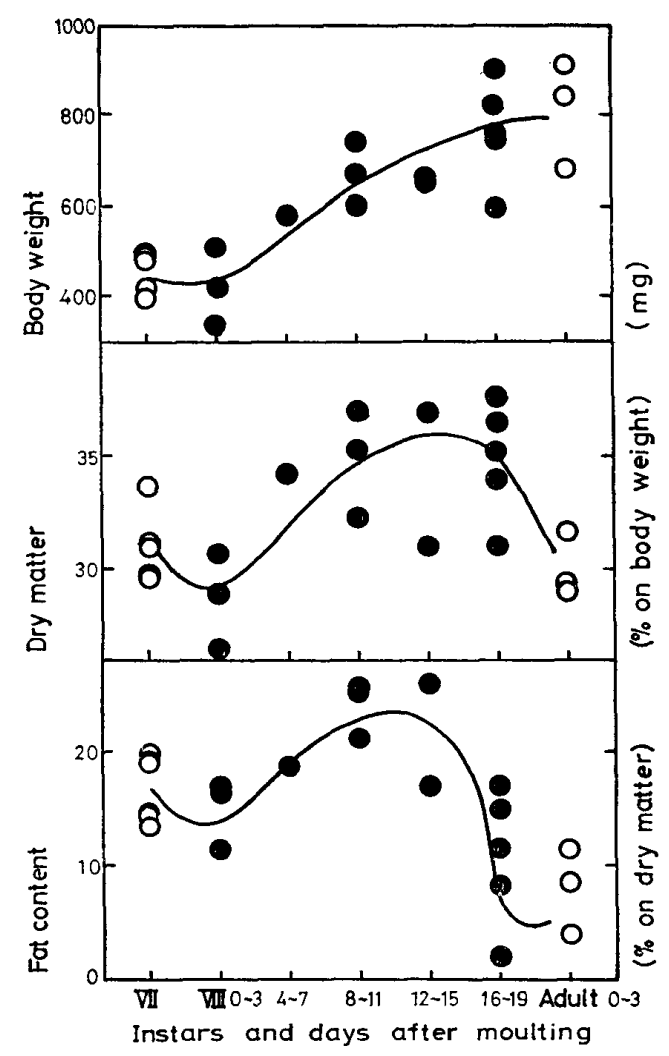

Fig. 3 Changes of body weight, dry matter, and fat content of older nymphs at $27^{\circ} \mathrm{C}-\mathrm{L}$ (Females) 
fat content decrease when the nymphs moult.

The results in males were similar to those in females.

IV. Adult emergence from final instar nymphs at $15^{\circ} \mathrm{C}-\mathrm{S}$

One hundred final instar nymphs (50仓 and 50 우) soon after moulting were taken from a stock colony which had been reared at $27^{\circ} \mathrm{C}$ - $\mathrm{L}$ for 90 days from their hatching, and were transferred to and reared at $15^{\circ} \mathrm{C}-\mathrm{S}$. No adult was found after 200 days of the $15^{\circ} \mathrm{C}-\mathrm{S}$ rearing, but 49 adults $(28 \hat{o}$ and 21 \% $)$ and 36 nymphs (17 $\delta$ and 19 우) were found on the 400th day. All the adults emerging were with abnormal wings (Fig. 4). Similar results have been reported before (Tsuji and Mizuno, 1972).

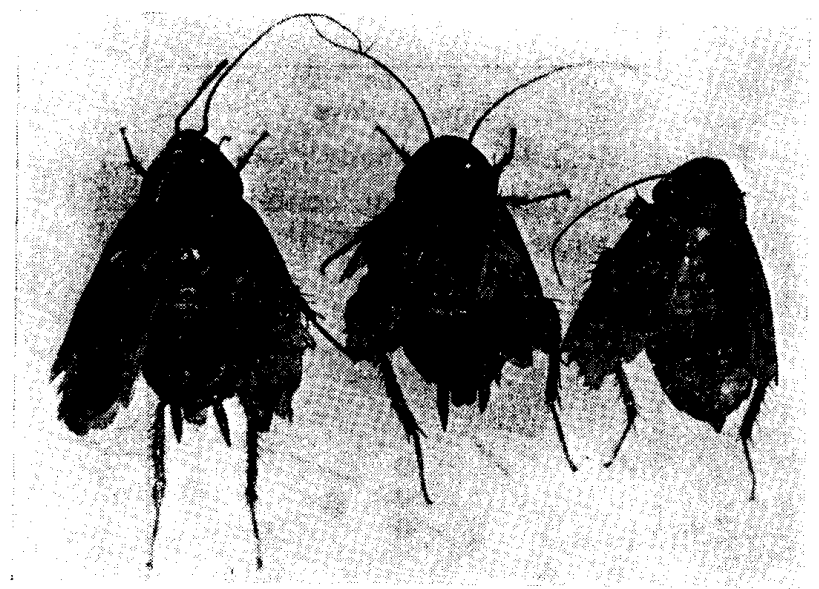

Fig. 4 Adults with abnormal wings emerging at $15^{\circ} \mathrm{C}-\mathrm{S}$

$V$. Development of young instar nymphs at $15^{\circ} \mathrm{C}-\mathrm{S}$

When reared at $20^{\circ} \mathrm{C}-\mathrm{S}$, nymphs of $P$. fuliginosa prolonged the duration of their second instar stage (Tsuji and Mizuno, 1972), but they showed no sufficient enhancement of resistance to cold (Tsuji and Mizuno, 1973). In order to examine the development of young nymphs at $15^{\circ} \mathrm{C}-\mathrm{S}$, measurement of head capsules was carried out with nymphs which had hatched at $27^{\circ} \mathrm{C}-\mathrm{L}$ within 2 days and were reared at $15^{\circ} \mathrm{C}-\mathrm{S}$. The results are shown in Fig. 5.

At $15^{\circ} \mathrm{C}-\mathrm{S}$, there was no instar-specific retardation of development and the rate of development was evenly decreased in all instars observed here. The head widths of

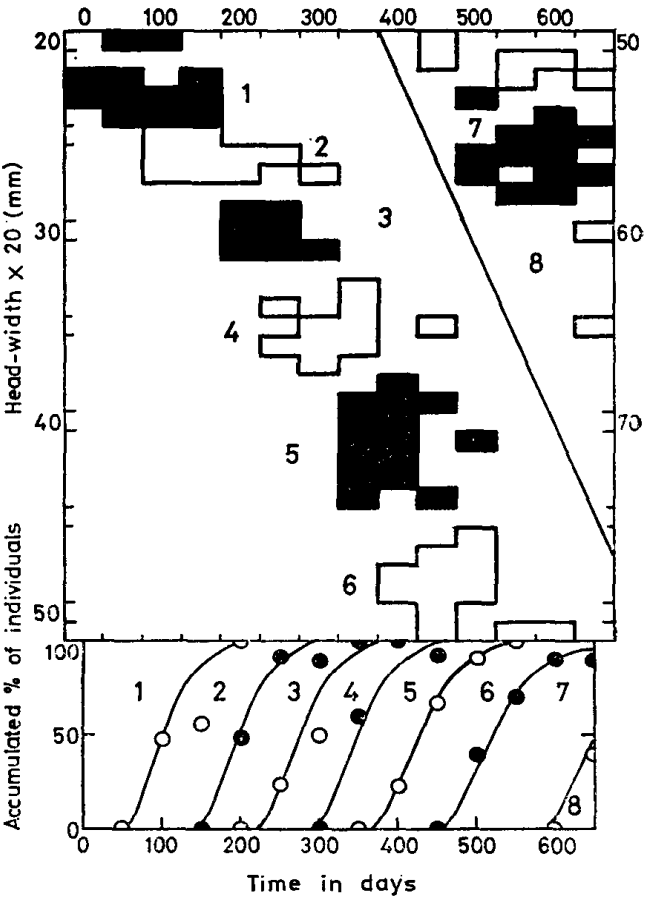

Fig. 5 Results of head-width measurements and accumulated moulting curves for younger nymphs at $15^{\circ} \mathrm{C}-\mathrm{S}$

घ : Distribution of measurments.

the nymphs older than the 2nd instar were smaller than those of corresponding instars at $27^{\circ} \mathrm{C}-\mathrm{L}$ (Tsuji and Mizuno, 1972), suggesting the existence of additional nymphal moults at lower temperatures.

\section{Resistance to cold in 1 st and 2nd instar} nymphs reared at $15^{\circ} \mathrm{C}-\mathrm{S}$

No first instar nymphs survived for 60 days at $5.5^{\circ} \pm 0.5^{\circ} \mathrm{C}$ even when previously reared for 40 days at $15^{\circ} \mathrm{C}-\mathrm{S}$ (Tsuji and Mizuno, 1973).

In the present study, nymphs hatching at $27^{\circ} \mathrm{C}-\mathrm{L}$ within $24 \mathrm{hr}$ and being reared at $15^{\circ} \mathrm{C}-\mathrm{S}$ for 155 days were chilled. Some were 2nd instar nymphs and others were still 1st instar ones on the 155th day. The nymphs were chilled in a glass container $(9 \mathrm{~cm}$ diameter, $6 \mathrm{~cm}$ depth) covered with a glass or wire-net lid. In some containers, a piece of food and/or a small bottle containing absorbent cotton with water was placed, and in others not.

The results are shown in Table 2. The 2nd instar nymphs could tolerate the chilling treatment for 60 days only when kept with water, whereas the 1st instar nymphs 
Table 2 Resistance to cold $\left(5.5^{\circ} \pm 0.5^{\circ} \mathrm{C}\right)$ in first and second instar nymphs reared at $15^{\circ} \mathrm{C} \cdot \mathrm{S}$

\begin{tabular}{|c|c|c|c|c|}
\hline Stage chilled & $\begin{array}{l}\text { Lid of test } \\
\text { container }\end{array}$ & $\begin{array}{l}\text { Additio } \\
\text { Water }\end{array}$ & Food & $\begin{array}{l}\text { co survival } \\
\text { of nymphs }\end{array}$ \\
\hline \multirow[t]{5}{*}{ First instar } & Glass & + & - & 0 \\
\hline & Glass & - & + & 0 \\
\hline & Glass & - & - & 0 \\
\hline & Wire net & + & + & 0 \\
\hline & Wire net & - & - & 0 \\
\hline \multirow[t]{5}{*}{ Second instar } & Glass & + & - & 90 \\
\hline & Glass & - & + & 0 \\
\hline & Glass & - & - & 0 \\
\hline & Wire net & + & + & 5.) \\
\hline & Wire net & - & - & 0 \\
\hline
\end{tabular}

Ten nymphs were used in each treatment.

could not at all. As 2nd instar nymphs reared at $20^{\circ} \mathrm{C}$-S could not tolerate the chilling treatment (Tsuji and Mizuno, 1973), those reared at $15^{\circ} \mathrm{C}-\mathrm{S}$ seem to be more resistant to cold.

\section{CONCLUSIONS AND SUMMARY}

A preliminary exposure of more than 28 days to $15^{\circ} \mathrm{C}-\mathrm{S}$ could induce final instar nymphs of $P$. fuliginosa to tolerate a chilling temperature $\left(5.5^{\circ} \pm 0.5^{\circ} \mathrm{C}\right)$ for 90 days (Table 1, and Tsuji and Mizuno, 1973). The exposure to $15^{\circ} \mathrm{C}$-S caused no extreme retardation of their development when returned to $27^{\circ} \mathrm{C}$-L (Fig. 1). No $15^{\circ} \mathrm{C}$-S-specific increase of fat content and dry matter was found in final instar nymphs (Figs. 2 and 3 ). Even at $15^{\circ} \mathrm{C}-\mathrm{S}$, final instar nymphs were able to become adults, though the adults emerging had abnormal wings (Fig. 4). Thus the nymphs seem to enhance their resistance to cold without entering "true diapause".

The rate of development in younger instar stages was evenly decreased at $15^{\circ} \mathrm{C}-\mathrm{S}$ (Fig. 5), and 2nd instar nymphs showed no such instar-specific retardation of development as observed at $20^{\circ} \mathrm{C}-\mathrm{S}$ (Tsuji and Mizuno, 1972). However, 2nd instar nymphs reared at $15^{\circ} \mathrm{C}-\mathrm{S}$ seem to be more resistant to cold (Table 2) than those reared at $20^{\circ} \mathrm{C}-\mathrm{S}$ (Tsuji and Mizuno, 1973).

\section{REFERENCES}

Andrewartha, H. G. (1952) : Diapause in relation to the ecology of insects. Biol. Rev., 27:50107.

Bodenheimer, F. S. (1952) : Arrested development and arrested activity in insect life. Trans. 9th Int. Congr. Ent., 1 : 21-40.

Bonnemaison, L. (1945): Arrêts de développement et diapauses. Ann. Epiphyt., $11: 19-56$.

Ikemoto, H. (1958) : Seasonal variations of water and lipid contents of a leaf-beetle, Aulacophora fumolaris Motschulsky. Jap. J. Appl. Ent. Zool., 2 : 119-122.

Lees, A. D. (1955) : The physiology of diapause in arthropods. $151 \mathrm{pp}$. Cambridge Univ. Press.

Tsuji, H. (1963) : Experimental studies on the larval diapause of the Indian-meal moth, Plodia interpunciella Hübner (Lepidoptera: Pyralidae). Thesis (Kyushu Univ., Fukuoka) 88pp., Kokodo Ltd., Tokyo.

Tsuji, H. (1965) : Studies on the behaviour pattern of feeding of three species of cockroaches, Blattella germanica, Periplaneta americana, and $P$. fuliginosa, with special reference to their responses to some constituents of rice bran and some carbohydrates. Jap. J. Sanit. Zool., 16 : 255-262.

Tsuji, H. and T. Mizuno (1972) : Retardation of development and reproduction in four species of cockroaches, Blattella germanica, Periplaneta americana, $P$. fuliginosa, and $P$. japonica, under various temperature conditions. Jap. J. Sanit. Zool., 23 : 101-111.

Tsuji, H. and T. Mizuno (1973): Effects of a low temperature on the survival and development of four species of cockroaches, Blattella 
germanica, Periplaneta americana, P. fuliginosa, and P. japonica. Jap. J. Sanit. Zool., 23: 185-194.

\section{摘要}

耐低温性に関連したクロゴキブリの発育

昆虫には越冬前に特定のステージで発育停止，すなわ ち休眠に入り，耐寒性を増加させ，そのステージに特異 的な水分含量低下，粗脂肪含量の堌大を示すをのが多 い.

クロゴキブリの大型幼虫は，あらかじめ $15^{\circ} \mathrm{C}$ 短日 (8 時間照明) 条件下で飼育すると， $5.5^{\circ} \mathrm{C}$ 低温に 90 日 以上耐えられる。

そこで，脱皮後間もない終令幼虫を $15^{\circ} \mathrm{C}$ 短日下で 150 日間飼育すると，その間脱皮は行われず，体重の増 大に伴い，含水率の低下，粗脂肪含有率の堌大がみられ そ。しかしこの変化は $15^{\circ} \mathrm{C}$ 短日下に特異的なものでは

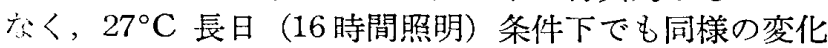

がみられた． $27^{\circ} \mathrm{C}$ では短期間で脱皮が起ったがその際 には含水率は上昇し，粗脂肪含有率は低下した。一方， $15^{\circ} \mathrm{C}$ 短日 60 日間飼育の後 $27^{\circ} \mathrm{C}$ 長日に戻した場合, 極端な羽化のおくれは認められなかった，又 $15^{\circ} \mathrm{C}$ 短日 に放置すれば，発育はおそいが 400 日で半数以上が羽化 した. したがって，クロゴキブリ終令幼虫の $15^{\circ} \mathrm{C}$ 短日 下での予備飼育による酎低温性の獲得は，休眠を伴って いないと思われる.

1 令幼虫加ら $15^{\circ} \mathrm{C}$ 短日下で飼育を行うと，ゆっくり ではあるが次々と脱皮発育し，650日で約 $40 \%$ が 8 令 （残りは $6 \sim 7$ 令）に達した。この 8 令幼虫は $27^{\circ} \mathrm{C}$ 飼育 の 8 令 $\left(27^{\circ} \mathrm{C}\right.$ では終令 $)$ より小型で，低温下では適温 下より脱皮回数が多くなることが暗示された. 又 $15^{\circ} \mathrm{C}$ 短日下では， $20^{\circ} \mathrm{C}$ 短日下でみられたような 2 令のみに 特異的な令期間の延長はみられなかった。しかし， $20^{\circ} \mathrm{C}$ 短日下で得られた 2 令幼虫が $5.5^{\circ} \mathrm{C}$ に 60 日間耐えられ なかったのに対し， $15^{\circ} \mathrm{C}$ 短日下で得られた 2 令幼虫は 60 90\%生存し，酎低温性が強まっていることがうか がわれた。 